\title{
PENGARUH PENDAMPINGAN PETUGAS PENGELOLA OBAT PUSKESMAS TERHADAP PERENCANAAN OBAT DAN KETERSEDIAAN OBAT DI KABUPATEN BUTON UTARA
}

\author{
Irnawati ${ }^{1}$, Sunarsih ${ }^{2}$, Ramadhan Tosepu ${ }^{3}$ \\ ${ }^{1,2,3}$ Program Studi Kesehatan Masyarakat STIKES Mandala Waluya Kendari \\ Email: irnawati1304@gmail.com
}

\begin{abstract}
ABSTRAK
PUSKESMAS adalah sebuah organiisasi yang memberikan fasilitas pelayanan kesehatan dalam upaya kesehatan masyarakat dan upaya kesehatan perseorangan tingkat pertama, dengan lebih mengutamakan upaya pertolongan pertama, untuk mencapai derajat kesehatan masyarakat yang setinggi-tingginya di wilayah kerjanya. Obat merupakan salah satu komponen utama ynng ada dalam PUSKESMAS dalam rangka pelayanan terhadap masyarakat yang sakit. Tujuan penelitian ini adalah Untuk mengetahui pendampingan pengelola obat Puskesmasdalam meningkatkan perencanaan obat dan ketersediaan obat di Kabupaten Buton Utara. Metode penelitian yang digunakan adalah metode penelitian kuantitatif dengan desain Pre Eksperimen yakni peneliti memberikan perlakuan pada responden penelitian. Hasil penelitian ini dapat menjadi bahan acuan dalam melakukan perencanaan obat sehingga ketersediaan obat di Puskesmas aman dan terjamin serta tepat sasaranserta menjadi acuan untuk pengembangan penelitian selanjutnya. Kesimpulan yang diperoleh bahwa terdapat peningkatan perencanaan obat dan ketersediaan obat terhadap pendampingan petugas pengelola obat puskesmas.
\end{abstract}

Kata Kunci: Puskesmas, Obat,Petugas Pengelola Obat, Pendampingan, Pendampingan

\begin{abstract}
PUSKESMAS is an organization that provides health care facilities in public health efforts and first-level individual health efforts, with more emphasis on first aid efforts, to achieve the highest level of public health in the working area. Medicine is one of the main components in the National Health Center in the context of service to the sick community. The purpose of this study was to determine the assistance of Puskesmas drug management in improving drug planning and drug availability in North Buton Regency. The research method used is a quantitative research method with a Pre Experiment design that is researchers give treatment to research respondents. The results of this study can be a reference in drug planning so that the availability of drugs in the health center is safe and secure as well as the target. he conclusion was that there was an increase in drug planning and availability of drugs to the assistance of the Puskesmas drug administrators.
\end{abstract}

Keywords:PUSKESMAS, medicine, medicine employeeadministrator, Mentoring. 


\section{PENDAHULUAN}

Program Indonesia Sehat merupakan salah satu program dari Agenda ke-5 Nawa Cita, yaitu meningkatkan kualitas hidup manusia Indonesia. Program ini didukung oleh program sektoral lainnya, yaitu Program Indonesia Pintar, Program Indonesia Kerja dan Program Indonesia Sejahtera(Kemenkes RI, 2015a).Program Indonesia Sehat selanjutnya menjadi program utama pembangunan kesehatan pada periode 2015-2019 yaitu program Indonesia Sehat dengan sasaran meningkatkan derajat kesehatan dan status gizi masyarakat melalui upaya kesehatan dan pemberdayaan masyarakat yang didukung dengan perlindungan finansial dan pemerataan pelayanan kesehatan yang dilaksanakan dengan 3 (tiga) pilar utama, yaitu paradigma sehat, penguatan pelayanan kesehatan dan Jaminan Kesehatan Nasional (JKN)(Kemenkes RI, 2015a).

Salah satu sasaran program kefarmasian sesuai Keputusan Menteri Kesehatan Republik Indonesia Nomor HK.01.07/Menkes/422/2017 yang di berlakukan pada tangal 29 agustus 2017 adalah indikator persentase ketersediaan obat dan vaksin di Puskesmas. Pada tahun 2017 target nasional untuk ketersediaan obat dan vaksin esensial sebesar $83 \%$ dan capaian $89,30 \%$. Capaian tertinggi persentase Puskesmas dengan ketersediaan obat dan vaksin esensial pada tahun 2017 sebesar 100\% dicapai oleh delapan Provinsi, yaitu Sumatera Barat, Bengkulu, Kepulauan Bangka Belitung, Bali, Nusa Tenggara Barat, Sulawesi Selatan, Sulawesi Barat dan Maluku. Sedangkan Provinsi dengan ketersediaan obat dan vaksin esensial terendah pertama dicapai oleh Provinsi Sumatera Selatan sebesar $52,40 \%$ dan yang kedua adalah provinsi Sulawesi Tenggara sebesar $57,20 \%$ (Kemenkes RI, 2018).

Menurut Kemenkes RI (2016) Puskesmas yang merupakan Unit Pelaksana Teknis Dinas Kesehatan Kabupaten/Kota yang bertanggungjawab menyelenggarakan pembangunan kesehatan di suatu wilayah kerja(Kemenkes RI, 2016).Penyediaan obat yang cukup, tepat dan berkualitas dalam jumlah yang sesuai dengan yang dibutuhkan sangat dipengaruhi oleh ketepatan permintaan dari unit pelayanan kesehatan, dalam hal ini Puskesmas. Dengan demikian pengelolaan obat dan penggunaan obat merupakan siklus yang saling berkaitan dan tidak dapat dipisahkan antara satu dengan yang lainnya(Kemenkes RI, 2015b).

Pada tahun 2017 di Provinsi Sulawesi Tenggara capaian ketersediaan obat dan vaksin esensial yang mencapai target hanya tujuh Kabupaten/Kota, yakni Kabupaten Konawe, Kolaka, Bombana, Buton Tengah, Bau-Bau masing-masing dengan capaian $100 \%$, Kota Kendari 93,3\% dan Kolaka timur 91,7\% sedangkan yang tidak mencapai target masih ada sepuluh Kabupaten yang salah satunya adalah Kabupaten Buton Utara dengan capaian 0\% (Data Seksi Binfar Dinkes Prov. Sultra, 2017). Untuk indikator penggunaan obat rasional (POR) pada tahun 2017 Provinsi Sulawesi Tenggara dengan target 66\%, hanya tujuh Kabupaten/Kota yang mencapai target, yakni Kabupaten Konawe 100\%, Kota Kendari 66,67\%, Konawe Utara 77,27\%, Wakatobi 70\%, Konawe Kepulauan $71,43 \%$, Kota Kendari $66,67 \%$ dan Buton Tengah 83,33\% yang tidak mencapai target masih terdapat sepuluh kabupaten/kota, yakni Buton Selatan 62,50\%, Konawe Selatan 43,48\%, Bombana 54,55\%, Kolaka 42,86\%, Kolaka Utara 12,58\%, Muna 0\%, Bau-Bau 11,76\%, Buton 46,15\%, Buton Utara 40\%, Muna Barat 40\% dan Kolaka Timur 58,33\% (Data Seksi Binfar Dinkes Prov. Sultra, 2017). 
Ketidakcukupan obat-obatan di Puskesmas dipengaruhi oleh berbagai faktor, perencanaan/perhitungan perkiraan kebutuhan obat yang tidak tepat, efektif dan efisien merupakan salah satu faktor yang sangat menentukan ketersediaan obat (Iwan Indriawan etal., 2014).Pendampingan merupakan strategi yang di gunakan dalam upaya meningkatkan mutu dan kualitas sumber daya manusia sehingga mampu mengidentifikasi masalah serta berupaya mencari alternatif pemecahan masalah yang di hadapi (Hidayah N, 2015).

Perencanaan kebutuhan obat merupakan aspek yang sangat penting dalam pengelolaan obat di Puskesmas karena dengan perencanaan kebutuhan obat yang tepat akan membuat ketersediaan obat dengan jenis dan jumlah yang cukup sesuai dengan kebutuhan (Winda Tiara Eunike, 2015). Perencanaan dilakukan untuk menghindari kekosongan dan kelebihan obat dengan menggunakan dasar-dasar metode yang dapat dipertanggungjawabkan dan telah ditentukan, yakni (1) metode pola penyakit (epidemiologi) atau perkiraan kunjungan pasien (2) metode konsumsi atau penggunaan obat, dan (3) metode kombinasi(Fairuz and Yustiawan, 2018).

Dalam mencapai tujuan Pemerintah untuk menjamin ketersediaan, keterjangkauan dan pemerataan obat, banyak program pelatihan, pertememuanmaupun sosialisasi yang dilakukan tentang manajemen kefarmasian untuk pengembangan keterampilan petugas pengelola obat di Puskesmas untuk meningkatkan pelayanan kesehatan dalam menjamin ketersediaan obat. Namun pelatihan tersebut tidak secara efektif memastikan kemampuan untuk menerjemahkan pengetahuan teoritis ke dalam praktek.Oleh karena itu dalam meningkatkan kinerja dan kemampuan petugas pengelola obat Puskesmas terutama dalam melakukan perencanaan kebutuhan obat dalam memenuhi ketersediaan obat di Puskesmas perlu dilakukan pendampingan dalam rangka pengembangan keterampilan dan kemapuan dalam merencanakan kebutuhan obat (Manzi Anatole et al., 2017).

Belum terlaksananya fungsi manajemen yang baik dan benar dalam pengelolaan obat baik dari perencanaan, pengorganisasian, pelaksanaan dan pengawasan di lingkup Dinas Kesehatan Kabupaten Buton Utara menyebabkan pengelolaan obat di Puskesmas belum berjalan sesuai standar yang di inginkan. Oleh karena ituperlunya dilakukan pendampingan petugas pengelola obat Puskesmas dalam meningkatkan derajat kesehatan masyarakat baikdari faktor lingkungan, perilaku, pelayanan kesehatan maupun dari faktor genetik.Disamping itu, tidak efektinya pelaksanaan pelatihan dan pertemuan tentang manajemen pengelolaan obat yang dilakukan di Dinas Kesehatan Kabupaten Buton Utara, sehingga perlu dilakukan pendampingan petugas pengelola obat Puskesmas dalam perencanaan kebutuhan obat dalam menjamin ketersediaan obat, sehingga dapat meningkatkan keterampilan, kemampuan, pengetahuan dan motivasi petugas pengelola obat Puskesms dalam melaksanakan pengelolaan obat yang baik, benar dan sesuai dengan yang ditetapkan.

Alasan penelitian ini dilakukan adalah untuk memberikan bimbingan dan pengetahuan terhadap petugas pengelola obat Puskesmas dalam hal melakukan perencanaan obat yang baik, tepat dan sesuai pedoman dari Kementerian Kesehatan RI sehingga ketersediaan obat di Puskesmas terjamin, berkhasiat dan terjangkau. Oleh karena itu langkah yang tepat dan efektif adalah dengan dilakukan pendampingan dalam kurun waktu tertentu sehingga petugas pengelola 
obat Puskesmas yang ada dapat memahami dan mengetahui hal-hal yang harus dilakukan dalam perhitungan kebutuhan obat yang tepat dan sesuai dengan kebutuhan sehingga ketersediaan obat tidak mengalami kekosongan dan kelebihan di Puskesmas. Diharapkan setelah proses pendampingan petugas pengelola obat Puskesmas dapat memilki catatan atau panduan yang dapat digunakan dalam proses pengelolaan obat, baik dan sesuai dengan kebutuhan.

\section{METODE PENELITIAN}

Ketepatan dan kebenaran data di Puskesmas akan berpengaruh terhadap ketersedian obat secara keseluruhan di Kabupaten atau Kota. Dalam proses perencanaan kebutuhan obat pertahun Puskesmas di minta menyediakan data pemakaian obat dengan menggunakan LPLPO(Kemenkes RI, 2010).

Jenis penelitian yang digunakan dalam penelitian ini adalah penelitian kuantitatif dengan desain Pre Eksperimen yakni peneliti memberikan perlakuan pada responden penelitian yang selanjutnya diobservasi efeknya.Perlakuan merupakan representatif dari variabel independent dan efek adalah representatif dari variabel dependen (Budiman, 2011). Dan mengunakan rancangan penelitian One group pretest-posttest desigh yakni suatu penelitian pre eksperimen dimana peneliti memberikan perlakuan pada kelompok studi tetapi sebelumnya diukur dahulu selanjutnya setelah perlakuan kelompok studi tersebut diukur kembali(Budiman, 2011)

Dalam melakukan pendampingan perencanaan kebutuhan obat dan ketersedian obat menggunakan pedoman materi pelatihan manajemen kefarmasian di Puskesmas yang di keluarkan oleh Direktorat Jenderal Bina Kefarmasian dan Alat Kesehatan Kementerian Kesehatan RI bekerjasama dengan Japan Internasional Cooperation Agency (JICA) tahun 2010, dengan menggunakan metode perhitungan kebutuhan obat dengan pola konsumsi (Kemenkes RI, 2010). Adapun kerangka yang digunakan pada penelitian ini dapat di lihat pada gambar di bawah ini:

Populasi penelitian ini adalah keseluruhan petugas pengelola obat Puskesmas se- Kabupaten Buton Utara yakni sebanyak 30 orang petugas pengelola obat. Sampel Penelitian dalam penelitian ini adalah sebanyak populasi

\section{HASIL DAN PEMBAHASAN}

\section{Hasil}

Hasil yang diperoleh berdasarkan karakteristik Responden yang terbagi tiga yaitu: umur, pendidikan dan jenis kelamin.

Tabel 1. Distribusi Responden Berdasarkan Kelompok Umur Petugas Pengelola Obat Puskesmas

\begin{tabular}{ccc}
\hline \multirow{2}{*}{ Kelompok Umur } & \multicolumn{2}{c}{ Jumlah } \\
\cline { 2 - 3 } & $\mathbf{n}$ & $\mathbf{\%}$ \\
\hline $22-26$ & 12 & $40 \%$ \\
$27-31$ & 12 & $40 \%$ \\
$32-36$ & 4 & $13,3 \%$ \\
$37-41$ & 2 & $6,7 \%$ \\
\hline Jumlah & 30 & $100 \%$ \\
\hline
\end{tabular}


Tabel 1, menunjukkan bahwa sebagian besar responden petugas dari kelompok umur 22 sampai 26 tahun yaitu sebanyak 12 responden (40\%)masih berusia muda sedangkan yang dianggap sudah berpengalaman hanya berjumlah 2responden $(6,7 \%)$

Tabel 2. Distribusi Responden Berdasarkan Tingkat Pendidikan Petugas Pengelola Obat Puskesmas

\begin{tabular}{ccc}
\hline Pendidikan & \multicolumn{2}{c}{ Jumlah } \\
\cline { 2 - 3 } & $\mathbf{n}$ & $\mathbf{\%}$ \\
\hline SPK & 3 & $10 \%$ \\
D3 & 14 & $46,67 \%$ \\
S1 & 6 & $20 \%$ \\
Apoteker & 7 & $23,33 \%$ \\
\hline Jumlah & 30 & $100 \%$ \\
\hline
\end{tabular}

Tabel 2, menunjukkan bahwa sebagian besar responden berpendidikan apoteker (Profesi) yaitu sebanyak 7 responden $(23,33 \%)$ sedangkan paling sedikit responden berpendidikan SPK sebanyak 3 responden $10 \%$.

Tabel 3. Distribusi Responden Berdasarkan Jenis Kelamin Petugas Pengelola Obat Puskesmas

\begin{tabular}{ccc}
\hline \multirow{2}{*}{ Jenis Kelamin } & \multicolumn{2}{c}{ Jumlah } \\
\cline { 2 - 3 } & $\mathbf{n}$ & \% \\
\hline Laki-Laki & 12 & $40 \%$ \\
Perempuan & 18 & $60 \%$ \\
\hline Jumlah & 30 & $100 \%$ \\
\hline
\end{tabular}

Tabel 3, menunjukkan bahwa kebanyakan responden petugas berjenis kelamin perempuan yaitu sebanyak 18 responden $(60 \%)$.

\section{Pembahasan}

\section{Peningkatan Perencanaan Obat Terhadap Pendampingan Petugas Pengelola Obat Puskesmas}

Perencanaan Kebutuhan obat di Puskesmas Kabupaten Buton Utara mengunakan metode konsumsi atau berdasarkan pemakaian rata-rata obat perbulan.Perencanaan kebutuhan obat Puskesmas merupakan kegiatan yang dilakukan dalam pemilihan jenis dan jumlah obat yang sesuai dengan kebutuhan untuk menghindari kekosongan dan kelebihan (penumpukan) obat di Puskesmas(Ivon Carolien et al., 2017)

Tabel 4. Peningkatan Perencanaan Obat terhadap Pendampingan Petugas Pengelola Obat Puskesmas di Kabupaten Buton Utara

\begin{tabular}{cccccc}
\hline \multirow{2}{*}{ Perencanaan Obat } & \multicolumn{3}{c}{ Waktu Pengukuran } & \multirow{2}{*}{ Pvalue } \\
\cline { 2 - 5 } & \multicolumn{2}{c}{ Pre test } & \multicolumn{2}{c}{ Post test } & -valu \\
\cline { 2 - 5 } & $\mathbf{n}$ & $\mathbf{\%}$ & $\mathbf{n}$ & $\mathbf{\%}$ & \\
\hline Kurang & 21 & $70 \%$ & 2 & $6 \%$ & \\
Cukup & 9 & $30 \%$ & 14 & $47 \%$ & \multirow{2}{*}{0,000} \\
Baik & 0 & $0 \%$ & 14 & $47 \%$ & \\
\hline Jumlah & 30 & $100 \%$ & 30 & $100 \%$ & \\
\hline
\end{tabular}


Hasil penelitian ini menunjukkan bahwa dari 10 responden yang diamati, sebelum pendampingan (pre-test) terdapat 21 responden $(70 \%)$ yang kurang perencanaan obatnya dikarenakan petugas pengelola obat Puskesmas tidak melakukan perhitungan stok optimal obat setiap bulannya, dikarenakan ketidaktahuan petugas pengelola obat Puskesmas dalam melakukan perhitungan karena tidak adanya pengetahuan dan bimbingan dari Petugas IFK tentang pentingnya perhitungan stok optimal, dimana stok optimal merupakan stok ideal obat yang harus tersedia dalam periode waktu tertentu di Puskesmas.Pengetahuan dan keterampilan tentang manajemen pengelolaan obat bagi petugas pengelola obat Puskesmas merupakan faktor utama yang mempengaruhi pelaksanaan kegiatan perencanaan obat yang baik (Ingrid N. Rumbay et al., 2015).

Setelah pendampingan (post-test) juga diketahui terdapat 14 responden $(47 \%)$ yang pelayanan obatnya cukup ini dikarenakan petugas pengelola obat Puskesmas telah mengetahui pentingnya dilakukan perhitungaan kebutuhan obat yang merupakan dasar dalam melakukan permintaan obat ke IFK namun dikarenakan masih adanya pemeriksaan pasien yang dilakukan bukan dari dokter sehingga masih menyebabkan penggunaan obat yang belum rasional, dan 14 responden (47\%) berubah menjadi baik perencanaan obatnya, karena petugas pengelola obat Puskesmas telah mengetahui dan memahami tata cara dan pentingnya perhitungan kebutuhan obat yang mana stok optimal wajib diisi di setiap LPLPO karena dalam perhitungan stok optimal sudah termuat waktu tunggu kekosongan obat dan buffer stok obat atau stok pengaman yang menjadi dasar dalam melakukan permintaan jenis dan jumlah obat yang tepat di IFK sehingga Petugas IFK tidak mempunyai alasan untuk tidak memberikan obat sesuai dengan permintaan yang di ajukan. Disamping itu, pelaporan dan pencatatan stok opname, obat kadarluasa/ hilang telah dilakukan dengan baik selain itu, dokter telah memahami tentang penggunaan obat yang rasional.

\section{Peningkatan Ketersediaan Obat Terhadap Pendampingan Petugas Pengelola Obat Puskesmas}

Ketersediaan obat dalam jenis dan jumlah yang tepat di Puskesmas merupakan salah satu faktor yang akan meningkatkan persepsi dan pandangan masyarakat terhadap kualitas pelayanan kesehatan di Pusksmas (Ivon Carolien et al., 2017).

Tabel 5. Peningkatan Ketersediaan Obat terhadap Pendampingan Petugas Pengelola Obat Puskesmas Di Kabupaten Buton Utara

\begin{tabular}{cccccc}
\hline \multirow{2}{*}{ Ketersediaan Obat } & \multicolumn{4}{c}{ Waktu Pengukuran } & \multirow{2}{*}{ P-Value } \\
\cline { 2 - 5 } & \multicolumn{2}{c}{ Pre test } & Post test & \\
\cline { 2 - 5 } & $\mathbf{n}$ & $\mathbf{\%}$ & $\mathbf{n}$ & $\boldsymbol{\%}$ & \\
\hline Kurang & 26 & $87 \%$ & 3 & $10 \%$ & \\
Cukup & 4 & $13 \%$ & 9 & $30 \%$ & 0,000 \\
Baik & 0 & $0 \%$ & 18 & $60 \%$ & \\
\hline Jumlah & 30 & $100 \%$ & 30 & $100 \%$ & \\
\hline
\end{tabular}

Setelah dilakukan pendampingan (post-test) juga diketahui terdapat 9 responden $(30 \%)$ ketersediaan obatnya cukup di pengaruhi oleh peningkatan pengetahuan dan keterampilan dalam melakukan perhitungan kebutuhan obat sehingga permintaan obat yang di sampaikan ke IFK sesuai dengan kebutuhan 
sehingga penerimaan obat yang di keluarkan dari IFK sesuai dan terjamin ketersediaan dan kecukupannya selama jangka waktu yang di tentukan, selain itu yang masih belum berubah adalah jenis obat masih belum mencapai target kesesuaian dengan Fornas/Doen dan 18 responden (60\%) berubah menjadi baik ketersediaan obatnya disebabkan pengelola obat Puskesmas telah memahami tentang perhitungan kebutuhan obat yang dapat menjamin ketersediaan dan kecukupan obat di Puskesmas dan dalam melakukan pemilihan jenis obat sudah memperhatikan fornas/Doen.

\section{SIMPULAN DAN SARAN}

\section{Simpulan}

Adapun kesimpulan dari penelitian ini adalah terdapat peningkatan perencanaan obat terhadap pendampingan petugas pengelola obat puskesmas, $\mathrm{p}=$ $0,000<0,05$, dan terdapat peningkatan ketersediaan obat terhadap pendampingan petugas pengelola obat Puskesmas, $\mathrm{p}=0,000<0,05$.

\section{Saran}

Adapun saran yang dapat diberikan adalah diharapkan kepada pihak Dinas Kesehatan atau Instalansi Farmasi Kabupaten untuk sering melakukan bimbingan atau pendampingan tentang manajemen pengelolaan obat pada petugas Pengelola Obat di Puskesmas, Diharapkan kepada pihak Dinas Kesehatan untuk membentuk formularium obat Kabupaten agar obat yang tersedia sesuai dengan kebutuhan masyarakat Kabupaten Buton Utara.Diharapkan Instalasi Farmasi Kabupaten (IFK) untuk selalu rutin melakukan monitoring dan evaluasi terhadap petugas pengelola obat Puskesmas sehingga dapat di ketahui kedala yang dihadapi di Puskesmas dalam perencanaan obat dan ketersediaan obat khususnya, serta permasalahan manajemen pengelolaan obat pada umumny.Untuk Dinas Kesehatan Kabupaten di harapkan dalan dalam penempatan petugas pengelola obat Puskesmas didasarkan pada profesi apoteker atau jurusan kefarmasian, bukan dari profesi lain.Diharapkan bagi Petugas Pengelola Obat Puskesmas untuk selalu berkomunikasi dengan dokter Puskesmas dalam hal perencanaan obat dan ketersediaan obat di Puskesmas dan untuk selalu meningkatkan wawasan dan pengetahuan dalam pelaksanaan manajemen pengelolaan obat yang baik dan benar.

\section{UCAPAN TERIMAKASIH}

Seluruh Kepala Puskesmas dan Petugas Pengelola Obat Puskesmas se Kabupaten Buton Utara yang telah membeikan dukungan pada penelitian ini.

\section{DAFTAR PUSTAKA}

BUDIMAN 2011. Penelitian Kesehatan, Bandung, PT. Refika Aditama.

DATA SEKSI BINFAR DINKES PROV. SULTRA 2017. Dinas Kesehatan Provinsi Sulawesi Tenggara.

FAIRUZ, N. A. \& YUSTIAWAN, T. 2018. Perhitungan Konsumsi Obat Untuk Logistik Medik di

Rumah Sakit Islam Jemursari Surabaya. JAKI 5 No. 2, 155-161. 
HIDAYAH N. 2015. Kajian Teori Pendampingan. http: //digilib.uinsby.ac.id/2014/5/bab\%202.pdf [Online].

INGRID N. RUMBAY, G.D KANDOU \& SOLEMAN, T. 2015. Analisis Perencanaan Obat di Dinas Kesehatan Kabupaten Minahasa. JIKMU, 5, 469-478.

IVON CAROLIEN, ACHMAD FUDHOLI \& DWI ENDARTI 2017. Evaluasi Ketersediaan Obat Sebelum dan Sesudah Implementasi JKN pada Puskesmas di Kabupaten Keerom Provinsi Papua. JURNAL Manajemen dan Pelayanan Farmasi 7 Nomor 1, 30-39.

IWAN INDRIAWAN, WAHID TRI WAHYUDI \& RAHAYUNINGSIH, A. 2014. Analisis Pengelolaan Obat di Puskesmas Gaya Baru V Kecamatan Bandar Surabaya Kabupaten Lampung Tengah. Jurnal Kesehatan Holistik

Volume 8, No 1, 1-6.

KEMENKES RI 2010. Materi Pelatihan Manajemen Kefarmasian di Puskesmas, Jakarta, Bina Kefarmasian dan Alkes Kemenkes RI dan Japan Internasional Cooperation Agency (JICA)

KEMENKES RI 2015a. Keputusan Menteri Kesehatan Republik Indonesia Nomor HK.02.02/MENKES/320/2015 tentang Daftar Obat Esensial Nasional, Jakarta, Kementerian Kesehatan RI.

KEMENKES RI 2015b. Modul Penggerakan Penggunaan Obat Rasional, Jakarta, Kementerian Kesehatan RI.

KEMENKES RI 2016. Peraturan Menteri Kesehatan Republik Indonesia Nomor 74 Tahun 2016 Tentang Standar Pelayanan Kefarmasian di Puskesmas Jakarta, Kementerian Kesehatan RI.

KEMENKES RI 2018. Laporan Kinerja 2017 Direktorat Jenderal Kefarmasian dan Alat Kesehatan, Jakarta, Kementerian Kesehatan RI.

MANZI ANATOLE, R., L., HIRSCHHORN, KENNETH SHERR, CINDY CHIRWA, C. B., JOHN KOKU AWOONOR-WILLIAMS \& THE AHI PHIT PARTNERSHIP COLLABORATIVE 2017. Mentorship and coaching to support strengthening healthcare systems: lessons learned across the five Population Health Implementation and Training partnership projects in sub-Saharan Africa. BMC Health Services Research, 17, 831.

WINDA TIARA EUNIKE 2015. Analisis Perencanaan Kebutuhan Obat di Puskesmas Rowosari Semarang Tahun 2015. Siadin Informasi. 